ISSN 1392-3196 / e-ISSN 2335-8947

Zemdirbyste-Agriculture, vol. 107, No. 2 (2020), p. 99-104

DOI $10.13080 / \mathrm{z}-\mathrm{a} .2020 .107 .013$

\title{
Development of herbicides resistance in Apera spica-venti in Lithuania
}

\author{
Ona AUŠKALNIENĖ, Gražina KADŽIENĖ, Rasa STEFANOVIČIENĖ, Birute JOMANTAITĖ \\ Lithuanian Research Centre for Agriculture and Forestry, Institute of Agriculture \\ Instituto 1, Akademija, Kèdainiai distr., Lithuania \\ E-mail: ona.auskalniene@lammc.lt
}

\begin{abstract}
For decades, farmers have been increasingly reliant on herbicides for effective weed management. Repetitive longterm application of herbicides with the same mode of action has resulted in the evolution of herbicide resistance woldwide. The crops most affected by weed resistance in Europe are winter cereals, and one of the worst weeds is silky bent grass (Apera spica-venti (L.) P. Beauv.). Seeds of A. spica-venti were collected from across Lithuania from the farmer's fields, where this weed was not controlled despite herbicide application. A total of 159 populations of $A$. spica-venti were tested in greenhause studies over the period of 2016-2018. In the experiments, the resistance of $A$. spica-venti to the following herbicides was assessed: methyliodosulphuron natrium, sulphosulphuron and pyroxsulam (aceto-lactate synthase (ALS) inhibitors), fenoxaprop-P-ethyl and pinoxaden (acetyl-coenzyme A carboxylase (ACCase) inhibitors) and isoproturon (photosystem II (PSII) inhibitor). It was found that of the 159 seed samples tested, $43 \%$ showed little response to ALS inhibitors, sulphosulphuron, methyliodosulphuron and pyroxulam. Most of the tested populations were resistant to sulphosulphuron, while the fewest populations were resistant to pyroxulam, but all populations resistant to pyroxulam were resistant to both other ALS inhibitors, methyliodosulphuron natrium and sulphosulphuron.

Growing resistance of $A$. spica-venti to ALS inhibitors will greatly restrict the choice of herbicides currently available for weed control in spring; therefore, autumn herbicide application in winter cereals in the future can become very important, especially in the fields, where $A$. spica-venti is highly distributed.
\end{abstract}

Key words: herbicide efficacy, herbicide resistance, silky bent grass, weed control.

\section{Introduction}

Weeds have been associated with human activity since the beginning of crop cultivation. It is a major problem in most cropping systems, and their control is essential for successful crop production. Weeds cause considerable economic costs to agriculture and natural resources in terms of crop loss, loss of land utility, health-related problems and the costs of control (Hamill et al., 2004). Besides these direct implications, weeds can also serve as alternate hosts to insect pests and pathogens, often resulting in additional operating costs and increased risk of diseases (Suproniene et al., 2019).

Weeds may be controlled manually, by mechanical weeding or by the use of synthetic herbicides.

The introduction of herbicides caused major changes in agriculture by reducing weeds, enabling early planting dates and causing less need for crop rotation. These tactics increased crop yield and quality and reduced the need for soil tillage (Hamill et al., 2004). Herbicides inhibit the activity of specific target enzymes associated with the catalysis of biosynthetic processes that are essential for plant growth (Powles, Yu, 2010).
For decades, globally, growers have been increasingly reliant on herbicides for effective weed management. Herbicides replaced the other weed management techniques as well as increased yield potential. In many countries with intensive agriculture, herbicides are used to the exclusion of all other weed control tactics, a phenomenon termed herbicide only syndrome (HOS) (Gaines, 2017). This in turn has facilitated the rise of new challenges in weed control, particularly the onset of herbicide resistance (Yuan et al., 2007; Burgos et al., 2013; Délye, 2013). According to $\mathrm{Yu}$ and Powles (2013), herbicide resistance is an evolutionary process which strongly depends on genetic factors weed species, herbicide and operational factors.

There are currently 502 unique cases of herbicide resistant weeds globally, with 258 weed species (150 dicots and 108 monocots); weeds have evolved resistance to 23 of the 26 known herbicide sites of action and to 167 different herbicides. Herbicide resistant weeds have been reported in 93 crops in 70 countries (Heap, 2019). The onset of herbicide resistance coupled with unpredictable

Please use the following format when citing the article:

Auškalnienė O., Kadžienė G., Stefanovičienė R., Jomantaitė B. 2020. Development of herbicides resistance in Apera spica-venti in Lithuania. Zemdirbyste-Agriculture, 107 (2): 99-104. DOI 10.13080/z-a.2020.107.013 
grain prices currently leaves crop production facing an uncertain future (Byrne et al., 2018). The crops most affected by weed resistance in the EU are winter cereals (Collavo, 2017). Due to increasing herbicide resistance and stricter legislation, chemical control of grass weeds in Europe has become more problematic (Clarke et al., 2000; Grundy, 2002; Duke, 2012).

Agricultural crops with different growth cycles (winter or spring) affect weed spread, germination and growth (Andrade et al., 2017). Grass weeds affect arable crops inflicting yield penalties, reducing crop quality and taking available nutrients away from the growing crop. Silky bent grass (Apera spica-venti (L.) P. Beauv.) is a winter annual weed that occurs in winter cereals. A. spica-venti produces short-lived seeds which typically germinate in the autumn and whose life cycles coincide with those of winter wheat (Jensen, 2009); therefore, the spread of this weed is promoted by crop rotations with a high proportion of winter cereals (Scherner et al., 2016). A. spica-venti is mainly widespread in Central and Eastern European countries, such as Germany, Poland and the Czech Republic as well as in some Northern European countries, such as Denmark and Sweden (Melander et al., 2008; Hamouzová et al., 2011).

Non-inversion soil tillage affects the emergence dynamics of $A$. spica-venti by prolonging the period during which emergence occurs (Scherner et al., 2017). The increase in recurrence of $A$. spica-venti infestations can be mainly attributed to the plasticity of this species in adaptation to different agricultural environments (Soukup et al., 2006; Melander et al., 2008). On the other hand, an increase in A. spica-venti populations is strong, when high proportion of winter wheat in crop rotations is combined with non-inversion soil tillage (Scherner et al., 2016; 2017).

Repetitive long-term application of herbicides with the same mode of action, mostly aceto-lactate synthase (ALS) inhibitors, together with the adoption of improper farm management strategies and measures, has resulted in the evolution of herbicide resistance in A. spica-venti as well as in many other weed species worldwide (Massa et al., 2013). The first recorded cases of herbicide resistance in $A$. spica-venti were to isoproturon in a biotype from Switzerland in 1994 (Mayor, Maillard, 1997) and subsequently in Germany (Niemann, 2000). At the beginning of the 1980's, a new group of herbicides inhibiting the activity of the ALS the first enzyme involved in the biosynthetic pathway of branched-chain amino acids (Durner et al., 1990) was launched into the market for the control of broad-leaved and grass weeds. These herbicides, known as ALS or AHAS (acetohydroxyacid synthase) inhibitors, have been used due to their high efficacy at low rates, low impact on non-target organisms, low residual activity and persistence and high selectivity in several crops (Moss, Cussans, 1991).

A number of $A$. spica-venti populations have now been documented with sulfonylurea herbicide (ALS inhibitors) resistance in Europe (Marczewska, Rola, 2005; Delabays et al., 2006; Niemann, Zwerger, 2006; Novakova et al., 2006; Massa, 2011; Massa, Gehards, 2011). Control failures of $A$. spica-venti in the fields of winter cereals are frequently encountered by farmers across Lithuania. The interest in reduced (non-inversion) soil tillage in Lithuania has emerged over the last decades as well. It was established that shallow ploughing and rototilling did not exert any negative effect on soil agrochemical and physical properties (Feiza et al., 2011), and shallow tillage can give similar yields to mouldboard ploughing (Arvidsson et al., 2014), nonetheless the amount of seeds in the soil, as well as weed mass was significantly higher in less disturbed systems particularly in reduced-tillage system (Auškalnienè et al., 2018; Kadziene et al., 2020).

Considering the information about farming practices in Lithuania and farmers' complaints about the low efficacy of herbicides, we suspected that A. spicaventi could be resistant to some active ingredients.

The objective of the present study was screening of $A$. spica-venti populations, collected from farmers' fields in Lithuania, for herbicide resistance at the greenhouse level using whole-plant bioassays (pot experiments) to verify actual resistance.

\section{Materials and methods}

Weed seeds were collected from across Lithuania over the period of 2014-2018 from conventional farmers' fields, where herbicides were ineffective with regard to the control of silky bent grass (Apera spicaventi (L.) P. Beauv., APESV according to EPPO Global Database). Seeds of $A$. spica-venti were taken in mid- to end July from multiple locations of the field to represent the whole field. One sample contained 50-60 panicles of $A$. spica-venti. During sample collection, blanks and headland were omitted. In the years 2014-2018, a total of 159 samples of $A$. spica-venti seeds were collected. The seeds were separated from panicles and purified under laboratory conditions. Then they were placed in a fridge at $-5^{\circ} \mathrm{C}$ for two weeks to disrupt the seed-dormancy period. Thus prepared seeds were examined under greenhouse conditions at the Institute of Agriculture, Lithuanian Research Centre for Agriculture and Forestry to determine their resistance to herbicides.

The greenhouse studies over the period of 20162018 included two stages of experiments. The first stage consisted of the application of one (recommended) dose of herbicides with different mechanisms of control. The purpose of the study was to select samples that did not respond or responded poorly to the applied herbicides and then to use these selected samples in further studies. In the experiments, the resistance of weeds to the following herbicides was assessed: methyliodosulphuron natrium, sulphosulphuron and pyroxsulam (aceto-lactate synthase (ALS) inhibitors), fenoxaprop-P-ethyl and pinoxaden (acetyl-coenzyme A carboxylase (ACCase) inhibitors) and isoproturon (photosystem II (PSII) inhibitor) (Table 1).

In the first stage of the study, only the recommended dose of the herbicide was applied. In the second stage, herbicides were applied at four doses: half dose, the recommended dose, double and quadruple doses. Susceptible and resistant biotypes of $A$. spica-venti from Aahrus University, Denmark were used as a standard in these studies, later after dose response experiments two A. spica-venti populations from Lithuania were choosen as standards: A44 susceptible and A144 resistant.

The pot experiments were located in the greenhouse. A total of 159 samples of A. spica-venti seeds were tested in 10 pot experiments. Greenhouse experiments were conducted in three replications in 
Table 1. Active ingredients of the herbicides used for the greenhouse resistance screening tests

\begin{tabular}{lccc}
\hline \multicolumn{1}{c}{$\begin{array}{c}\text { Active } \\
\text { ingredient (a.i.) }\end{array}$} & $\begin{array}{c}\text { Amount } \\
\mathrm{g} \mathrm{kg} \mathrm{L}^{-1} \text { a.i. }\end{array}$ & $\begin{array}{c}\text { Applied dose } \\
\mathrm{g} \mathrm{ha}^{-1} \text { a.i. } \\
\text { as recommended }\end{array}$ & $\begin{array}{c}\text { Herbicide Resistance } \\
\text { Action Committee (HRAC) } \\
\text { group of a.i. }\end{array}$ \\
\hline Pinoxaden & 50 & 45 & A (ACCase) \\
Fenoxaprop-P-ethyl & 69 & 82.8 & A (ACCase) \\
Methyliodosulphuron natrium & 10 & 10 & B (ALS) \\
Pyroxulam & 50 & 10 & B (ALS) \\
Sulphosulphuron & 750 & 20 & B (ALS) \\
Isoproturon & 500 & 1500 & C (PSII) \\
\hline
\end{tabular}

plastic pots (Popelmann, Germany) $9 \times 9 \times 8 \mathrm{~cm}$. Garden soil mixed with sand at a ratio of 3:1 was used for the experiments. Seeds of $A$. spica-venti were sown in each pot, and after emergence the seedlings were thinned, so that 20 plants were left in each pot. Postemergence treatments were applied, when plants of $A$. spica-venti were at the 3-leaf to 1-tiller growth stage. Herbicide treatments were carried out using a precision spray chamber (Schachtner Gerätetechnik, Germany). The delivery volume was calibrated to spray $300 \mathrm{~L} \mathrm{ha}^{-1}$; the distance from sprayed surface was $60 \mathrm{~cm}$, spraying pressure was $300 \mathrm{kPa}$. The temperature in the greenhouse was $20-25^{\circ} \mathrm{C}$, and the length of day/night was $16 / 8 \mathrm{~h}$. Visual evaluation of treatment effects was conducted 4 weeks after application (WAT4). Visible symptoms on surviving plants were expressed as a percentage $(0 \%-$ no survival, $100 \%$ - plants without any visible damage) of the untreated pots for the same population (Fig. 1).

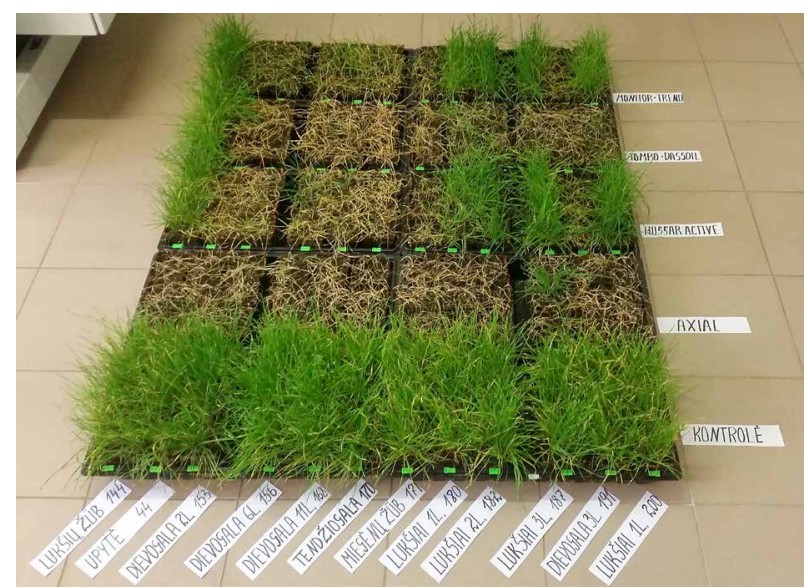

Figure 1. The efficacy of the herbicides on different populations of Apera spica-venti

In the first stage of the research, 6 herbicides were used at recommended rates. On this basis, biotypes which were not controlled or very poorly controlled were selected. In the second stage, methyliodosulphuron natrium and pyroxulam were used for dose response experiments.

Field experiments. Three field experiments were carried out in winter wheat (Triticum aestivum L.) in the fields with naturally high infestations (150-600 plants $\mathrm{m}^{-2}$ ) of $A$. spica-venti in 2012-2013 and 2013-2014. The experiments were conducted in two farmers' fields (Kalvarija municipality and Šakiai district) in two seasons. The fields were chosen based on farmers' complaints about the low efficacy of herbicdes against $A$. spica-venti. Field histories showed that winter wheat was grown for at least three years in succession in the same place and ALS inhibitors for the weed control were used.

These field experiments evaluated the efficacy of methyliodosulphuron natrium, isoproturon fenoxapropP-ethyl, pinoxaden and sulphosulphuron under field conditions. The experimental design was a randomised complete block with four replications, and each plot was $2.5 \times 9 \mathrm{~m}$ in size. Herbicides were applied using a plot sprayer with five nozzles (Hardi International A/S, Denmark) at a pressure of $200 \mathrm{kPa}$ and spray volume of $200 \mathrm{~L} \mathrm{ha}^{-1}$. Herbicide efficacy was evaluated according to the PP1/93(3) EPPO guidelines (2007) (https://www. eppo.int) by visual ratings and expressed as a percentage: untreated $=0 \%$, full control $=100 \%$.

Statistical analysis of herbicide efficacy in field trials was carried out using one-way analysis of variance (ANOVA), followed by Fisher's test $(P=0.05)$ from software package Selekcija (Raudonius, 2017).

\section{Results and disscussion}

During the period of 2014-2018, a total of 159 seed samples of $A$. spica-venti were collected from the farmers' fields. For all those samples, greenhouse experiments to test the efficacy of herbicides at recomended rates were done. Nearly half of the tested samples of $A$. spica-venti showed low efficacy against herbicides, especially ALS inhibitors: sulphosulphuron and methyliodosulphuron natrium. No resistance of the tested A. spica-venti were recorded to ACCase and PSII herbicides (Fig. 2).

Of the total biotypes of $A$. spica-venti tested, $43 \%$ were found to be resistant. Of the tested populations, 69 showed resistence to sulphosulphuron. All populations resistant to pyroxulam showed low efficacy against both other ALS inhibitors - sulphosulphuron and methyliodosulphuron. Similar results were found in Poland, where $52.4 \%$ of the tested $A$. spica-venti populations were resistant. Nearly $50 \%$ of the analysed samples exhibited resistance to sulfonylurea herbicides, wheareas resistance to ACCase inhibitors and isoproturon was less common (Adamczewski et al., 2019). Almost all A. spica-venti populations showed susceptibility to ACCase - pinoxaden in particular. Pinoxaden is widelly used for A. spica-venti control in Lithuania. Investigations in the United Kingdom and other countries showed that wide use of other ACCase substances, fenoxaprop-Pethyl, has resulted in a high incidence of resistance on Alopecurus myosuroides (Brown et al., 2002; Delye et al., 2010); therefore, with increasing use of ACCase we could expect emergence of resistance to this active ingredient in the nearest future. 


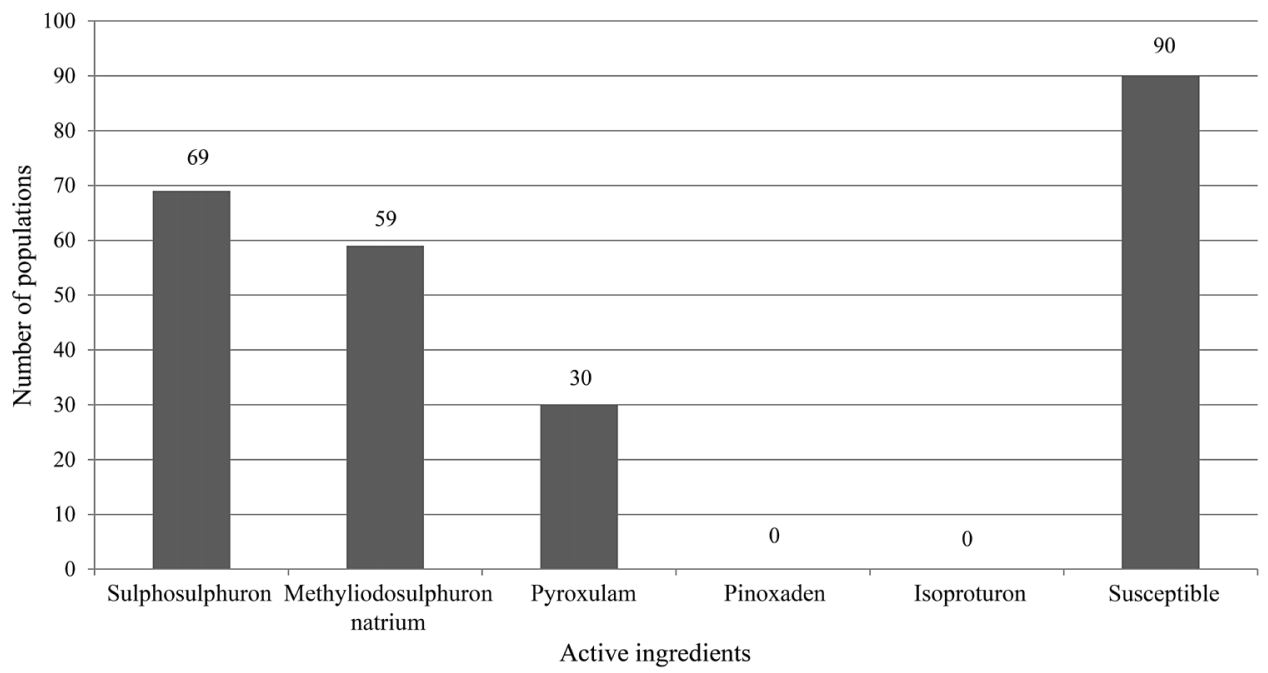

Figure 2. The number of resistant and susceptible populations of Apera spica-venti to herbicides

Growing resistance of A. spica-venti to ALS inhibitors greatly restricts the choice of herbicides available for weed control in spring; therefore, autumn herbicide application in winter cereals in the future can become very important, because they belong to other HRAC groups (http://www.hracglobal.com). A confirmation of this proposition could be investigations conducted in Latvia. According to Vanaga et al. (2010), application of herbicides in spring could not provide good control of $A$. spica-venti up to harvest time, when the infestation of this weed species at the application time was very high (more than 140 plants per $\mathrm{m}^{2}$ ). All herbicide treatments significantly increased crop yield, but the autumn applications gave significantly greater increases than nearly all spring applications.

Populations of A. spica-venti for dose response experiment were selected considering the results of previous experiments - those populations showed resistance to all three ALS inhibitors used at full rates: 8 populations and 2 standards (susceptible and resistant) of A. spica-venti were tested for different rates of two active ingredients (a.i.): methyliodosulphuron natrium at rates 10,20 and $40 \mathrm{~g} \mathrm{ha}^{-1}$ a.i. and pyroxulam at rates $5,10,20$ and $40 \mathrm{~g} \mathrm{ha}^{-1}$ a.i. Investigations showed that of the tested populations, five were resistant to the forth rate of the tested herbicides (Table 2).

Table 2. The efficacy of different rates (N) of herbicides, methyliodosulphuron and pyroxulam, on Apera spica-venti (APESV) populations, $\%$

\begin{tabular}{|c|c|c|c|c|c|c|c|c|}
\hline \multirow{2}{*}{$\begin{array}{l}\text { APESV } \\
\text { population }\end{array}$} & \multicolumn{4}{|c|}{$\begin{array}{l}\text { Methyliodosulphuron natrium } \\
\text { (recommended rate) }\end{array}$} & \multicolumn{4}{|c|}{$\begin{array}{c}\text { Pyroxulam } \\
\text { (recommended rate) }\end{array}$} \\
\hline & $0.5 \mathrm{~N}$ & $1 \mathrm{~N}$ & $2 \mathrm{~N}$ & $4 \mathrm{~N}$ & $0.5 \mathrm{~N}$ & $1 \mathrm{~N}$ & $2 \mathrm{~N}$ & $4 \mathrm{~N}$ \\
\hline A44 susceptible & $90-92$ & 100 & 100 & 100 & 97 & 100 & 100 & 100 \\
\hline A144 resistant & 0 & 0 & 0 & 0 & 0 & 0 & 0 & 0 \\
\hline A81 & 0 & 0 & 0 & $30-40$ & 0 & 0 & 0 & $30-40$ \\
\hline A82 & 0 & 0 & 0 & $40-50$ & 0 & 0 & $30-40$ & $70-75$ \\
\hline A91 & 0 & 0 & 0 & $40-50$ & 0 & 0 & $30-40$ & $40-50$ \\
\hline A122 & 0 & 0 & $30-40$ & $40-50$ & 0 & $60-70$ & $70-75$ & $93-95$ \\
\hline A123 & 0 & 0 & $65-70$ & $80-85$ & 0 & $50-60$ & $70-75$ & $80-85$ \\
\hline A263 & 0 & 0 & 0 & 0 & 0 & 0 & 0 & 0 \\
\hline A264 & 0 & 0 & 0 & 0 & 0 & 0 & 0 & 0 \\
\hline A266 & 0 & 0 & 0 & 0 & 0 & 0 & 0 & 0 \\
\hline
\end{tabular}

Doses higher than $5 \mathrm{~g} \mathrm{ha}^{-1}$ a.i. (half rate) of methyliodosulphuron natrium controlled the susceptible biotypes completely, but they did not exert any visible influence on resistant biotypes.

Table 3. The mean values of herbicide efficacy $(\%$ of untreated control; untreated control $=0)$ under field conditions 6 weeks after application on Apera spica-venti (APESV) populations

\begin{tabular}{|c|c|c|c|c|}
\hline \multirow{2}{*}{$\begin{array}{c}\text { Active } \\
\text { ingredient (a.i.) }\end{array}$} & \multirow{2}{*}{$\begin{array}{l}\text { Applied dose } \\
\mathrm{g} \mathrm{ha}^{-1} \text { a.i. }\end{array}$} & \multicolumn{2}{|c|}{ 2012-2013 } & \multirow{2}{*}{$\frac{2013-2014}{\text { Kalvarija (F1) }}$} \\
\hline & & Kalvarija (F1) & Šakiai (F2) & \\
\hline Fenoxaprop-P-ethyl & 82.8 & 70 & 100 & 80 \\
\hline Pinoxaden & 45.0 & 95 & 99 & 96 \\
\hline Isoproturon & 1500 & 83 & 92 & 87 \\
\hline Methyliodosulphuron natrium & 10 & $10 * *$ & 100 & $0 * *$ \\
\hline Pyroxulam & 10 & 100 & 96 & 100 \\
\hline Sulphosulphuron & 20 & 89 & $20 * *$ & 92 \\
\hline $\begin{array}{c}F \text {-ratio } \\
P \text {-value }\end{array}$ & & $\begin{array}{c}211.8 \\
<0.001\end{array}$ & $\begin{array}{c}177.9 \\
<0.001\end{array}$ & $\begin{array}{c}332.1 \\
<0.001\end{array}$ \\
\hline
\end{tabular}

In the field experiments, the efficacy of methyliodosulphuron natrium and sulphosuphuron against $A$. spica-venti was low (Table 3).

** - significant at $99 \%$ probability level 
The tested herbicides methyliodosulphuron natrium (Kalvarija F1) and sulphosulphuron (Šakiai F2), showed low efficacy ( $0 \%$ to $20 \%$ ) against Apera spicaventi. After the test in pot experiment (data not shown), it was founded that both populations from those fields were controlled by a full rate of methyliodosulphuron and sulphosulphuron in the greenhouse conditions, whereas the standard susceptible population of $A$. spica-venti was controlled by a half rate, and the standard resistant population survived in the pots treated with quadruple rate of the tested herbicides. Similar results were obtained by other researchers (Hamouzová et al., 2011; Massa et al., 2011).

\section{Conclusions}

1. Herbicide resistance is a problem in Lithuania - of the 159 seed samples tested, 43\% showed little response to aceto-lactate synthase (ALS) inhibitors, sulphosulphuron, methyliodosulphuron natrium and pyroxulam. Most of the tested populations were resistant to sulphosulphuron, while the fewest populations were resistant to pyroxulam.

2. All populations resistant to pyroxulam were found to be resistant to both other ALS inhibitors, methyliodosulphuron natrium and sulphosulphuron.

3. Not all Apera spica-venti populations tested showed resistance to herbicides. Other factors, including lower rates, meteorological conditions and weed development stage, might be responsible for the low efficacy of the herbicides against $A$. spica-venti.

4. Growing resistance of $A$. spica-venti to ALS inhibitors greatly restricts the choice of herbicides available for weed control in spring; therefore, autumn herbicide application in winter cereals in the future can become immensely important, especially in the fields, where $A$. spica-venti is highly distributed. Consequently, novel tools for integrated management of $A$. spica-venti should be developed.

Received 26082019 Accepted 27012020

\section{References}

1. Adamczewski K., Matysiak K., Kierzek R., Kaczmarek S. 2019. Significant increase of weed resistance to herbicides in Poland. Journal of Plant Protection Research, 59 (2): $139-150$

2. Andrade J. F., Satorre E. H., Ermacora C. M., Poggio S. L. 2017. Weed communities respond to changes in the diversity of crop sequence composition and double cropping. Weed Research, 57 (3): 148-158. https://doi.org/10.1111/wre 12251

3. Arvidsson J., Etana A., Rydberg T. 2014. Crop yield in Swedish experiments with shallow tillage and no-tillage 1983-2012. European Journal of Agronomy, 52: 307-315. https://doi.org/10.1016/j.eja.2013.08.002

4. Auškalnienė O., Kadžienè G., Janušauskaitė D., Supronienė S 2018. Changes in weed seed bank and flora as affected by soil tillage systems. Zemdirbyste-Agriculture, 105 (3): 221-226. https://doi.org/10.13080/z-a.2018.105.028

5. Brown A. C., Moss S. R., Wilson Z. A. Field L. M. 2002. Anisoleucine to leucine substitution in the ACCase of Alopecurus myosuroides (black-grass) is associated with resistance to the herbicide sethoxydim. Pesticide Biochemistry and Physiology, 72: 160-168. https://doi.org/10.1016/S0048-3575(02)00004-4

6. Burgos N. R., Tranel P. J., Streibig J. C., Davis V. M., Shaner D., Norsworthy J. K., Ritz Ch. 2013. Review: confirmation of resistance to herbicides and evaluation of resistance levels. Weed Science, 61: 4-20. https://doi.org/10.1614/WS-D-12-00032.1

7. Byrne R., Spink J., Freckleton R., Neve P., Barth S. 2018. A critical review of integrated grass weeds management in Ireland. Irish Journal of Agricultural and Food Research, 57: 15-28. https://doi.org/10.1515/ijafr-2018-0003

8. Clarke J., Moss S., Orson J. 2000. The future for grass weeds management in the U.K. Pesticide Outlook, 11: 59-63. https://doi.org/10.1039/b006322n

9. Collavo A. 2017. Overview of herbicide resistance in Europe. Proceedings of the conference Global Herbicide Resistance Challenge. Denver, USA, p. 18

10. Delabays N., Mermillod G., Bohren C. 2006. First case of resistance to sulfonylurea herbicides reported in Switzerland: a biotype of loose silky-bent (Apera spicaventi (L.) Beauv.). Journal of Plant Diseases and Protection, XX: 89-94.

11. Délye C. 2013. Unravelling the genetic bases of nontarget-sitebased resistance (NTSR) to herbicides: a major challenge for weed science in the forthcoming decade. Pest Management Science, 69: 176-187. https://doi.org/10.1002/ps.3318

12. Delye C., Michell S., Chauvell B., Brunel D., Guillemin J. P., Dessaint F., Le Corre1 V. 2010. Geographical variation in resistance to acetyl-coenzyme A carboxylase-inhibiting herbicides across the range of the arable weed Alopecurus myosuroides (black-grass). New Phytologist, 186: 1005-1017. https://doi.org/10.1111/j.1469-8137.2010.03233.x

13. Duke S. 2012. Why has no new herbicide modes of action appeared in recent years? Pest Management Science, 68: 505-512. https://doi.org/10.1002/ps.2333

14. Durner J., Gailus V., Boger P. 1990. New aspects on inhibition of plant acetolactate synthase by chlorsulfuron and imazaquin. Plant Physiology, 95: 1144-1149. https://doi.org/10.1104/pp.95.4.1144

15. Feiza V., Feiziene D., Kadziene G., Lazauskas S., Deveikyte I., Slepetiene A., Seibutis V. 2011. Soil state in the $11^{\text {th }}$ year of three tillage systems application on a cambisol. Journal of Food, Agriculture and Environment, $9(3-4): 1088-1095$.

16. Gaines T. 2017. GHRC: challenge accepted. Proceedings of the conference Global Herbicide Resistance Challenge. Denver, USA, p. 16.

17. Grundy A. C. 2002. Predicting weed emergence: a review of approaches and future challenges. Weed Research, 43: 1-11. https://doi.org/10.1046/j.1365-3180.2003.00317.x

18. HamillA. S., Holt J. S., Mallory-Smith C.A. 2004. Contributions of weed science to weed control and management. Weed Technology, 18: 1563-1565. https://doi.org/10.1614/0890037X(2004)018[1563:COWSTW]2.0.CO;2

19. Hamouzová K., Soukup J., Jursik M., Hamouz P., Venclova P., Tumova P. 2011. Cross-resistance to three frequently used sulfonylurea herbicides in populations of Apera spica-venti from the Czech Republic. Weed Research, 51 (2): 113-122. https://doi.org/10.1111/j.1365-3180.2010.00828.x

20. Heap I. 2019. International Survey of Herbicide Resistant Weeds. www.weedscience.org

21. Jensen P. K. 2009. Longevity of seeds of four annual grass and two dicotyledon weed species as related to placement in the soil and straw disposal technique. Weed Research, 49: 592-601. https://doi.org/10.1111/j.1365-3180.2009.00725.x

22. Kadziene G., Suproniene S., Auskalniene O., Pranaitiene S. Svegzda P., Versuliene A., Ceseviciene J., Janusauskaite D., Feiza V. 2020. Tillage and cover crop influence on weed pressure and Fusarium infection in spring cereals. Crop Protection, 127 (in press). https://doi.org/10.1016/j.cropro.2019.104966

23. Marczewska K., Rola H. 2005. Biotypes of Apera spicaventi and Centaurea cyanus resistant to chlorsulfuron in Poland. Proceedings of $13^{\text {th }}$ EWRS Symposium. Bari, Italy, p. 197.

24. Massa D. 2011. Investigations on herbicide resistance in Apera spica-venti populations: thesis of doctoral dissertation. University of Hohenheim, $82 \mathrm{p}$.

25. Massa D., Gerhards R. 2011. Investigations on herbicide resistance in European silky bent grass (Apera spica-venti) populations. Journal of Plant Diseases and Protection, 118 (1): 31-39. https://doi.org/10.1007/BF03356378 
26. Massa D., Krenz B., Gerhards R. 2011. Target-site resistance to ALS-inhibiting herbicides in Apera spica-venti populations is conferred by documented and previously unknown mutations. Weed Research, 51: 294-303. https://doi.org/10.1111/j.1365-3180.2011.00843.x

27. Massa D., Kaiser Y. I., Andújar-Sánchez D., CarmonaAlférez R., Mehrtens J., Gerhards R. 2013. Development of a Geo-Referenced database for weed mapping and analysis of agronomic factors affecting herbicide resistance in Apera spica-venti L. Beauv. (silky windgrass). Agronomy, 3: 13-27. https://doi.org/10.3390/agronomy3010013

28. Mayor J. P., Maillard A. 1997. A wind bentgrass biotope resistant to the herbicide isoproturon found in changins. Revue Suisse d'Agriculture, 29 (1): 39-44 (in French).

29. Melander B., Holst N., Jensen P. K., Hansen E. M., Olesen J. E. 2008. Apera spica-venti population dynamic and impact on crop yield as affected by tillage, crop rotation, location and herbicide programmes. Weed Research, 48 (1): 48-57. https://doi.org/10.1111/j.1365-3180.2008.00597.x

30. Moss S. R., Cussans G. W. 1991. The development of herbicide-resistant populations of Alopecurus myosuroides (black-grass) in England. Caseley J. C. et al. (eds). Herbicide resistance in weeds and crops. Oxford, UK, p. 45-56. https://doi.org/10.1016/B978-0-7506-1101-5.50006-1

31. Niemann P. 2000. Resistenz von Windhalm (Apera spica-venti) gegenüber Isoproturon. Mitteilungen der Biologischen Bundesanstalt für Land- und Forstwirtschaft, 376: 147-148 (in German).

32. Niemann P., Zwerger P. 2006. On herbicide resistance within Apera spica-venti (L.) P.B. Journal of Plant Diseases and Protection, XX: 81-88 (in German).

33. Novakova K., Soukup J., Wagner J., Hamouz P., Namestek J. 2006. Chlorsulfuron resistance in silky bent-grass (Apera spica-venti (L.) Beauv.) in the Czech Republic. Journal of Plant Diseases and Protection, XX: 139-146.

34. Powles S. B., Yu Q. 2010. Evolution in action: plants resistant to herbicides. Annual Review of Plant Biology, 61: 317-347.

https://doi.org/10.1146/annurev-arplant-042809-112119
35. Raudonius S. 2017. Application of statistics in plant and crop research: important issues. Zemdirbyste-Agriculture, 104 (4): 377-382. https://doi.org/10.13080/z-a.2017.104.048

36. Scherner A., Melander B., Kudsk P. 2016. Vertical distribution and composition of weed seeds within the plough layer after eleven years of contrasting crop rotation and tillage schemes. Soil and Tillage Research, 161: 135-142. https://doi.org/10.1016/j.still.2016.04.005

37. Scherner A., Melander B., Jensen P. K., Kudsk P., Avila L. A. 2017. Reducing tillage intensity affects the cumulative emergence dynamics of annual grass weeds in winter cereals. Weed Research, 57: 314-322. https://doi.org/10.1111/wre.12263

38. Soukup J., Novakova K., Hamouz P., Namestek J. 2006. Ecology of silky bent grass (Apera spica-venti (L.) Beauv.), its importance and control in the Czech Republic. Journal of Plant Diseases and Protection, XX: 73-80.

39. Suproniene S., Kadziene G., Irzykowski W., Sneideris D., Ivanauskas A., Sakalauskas S., Serbiak P., Svedzda P., Auskalniene O., Jedryczka M. 2019. Weed species within cereal crop rotations can serve as alternative hosts for Fusarium graminearum causing Fusarium head blight of wheat. Fungal Ecology, 37: 30-37.

https://doi.org/10.1016/j.funeco.2018.10.002

40. Vanaga I., Mintale Z., Smirnova O. 2010. Control possibilities of Apera spica-venti (L.) P. Beauv. in winter wheat with autumn and spring applications of herbicides in Latvia. Agronomy Research, 8 (spec. iss. II): 493-498.

41. Yu Q., Powles S. B. 2013. Herbicide-resistant weeds: from research and knowledge to future needs. Evoliutonary Applications, 6 (8): 1218-1221. https://doi.org/10.1111/eva.12098

42. Yuan J. S., Tranel P. J., Stewart C. N. 2007. Non-targetsite herbicide resistance: a family business. Trends in Plant Science, 12: 6-13. https://doi.org/10.1016/j.tplants.2006.11.001

ISSN 1392-3196 / e-ISSN 2335-8947

Zemdirbyste-Agriculture, vol. 107, No. 2 (2020), p. 99-104

DOI $10.13080 / \mathrm{z}-\mathrm{a} .2020 .107 .013$

\title{
Dirvinès smilguolès atsparumo herbicidams vystymasis Lietuvoje
}

\author{
O. Auškalnienè, G. Kadžienė, R. Stefanovičienè, B. Jomantaitė
}

Lietuvos agrarinių ir miškų mokslų centro Žemdirbystès institutas

\section{Santrauka}

Ilgalaikis herbicidų su tomis pačiomis veikliosiomis medžiagomis naudojimas sąlygojo piktžolių atsparumo jiems išsivystymą. Europoje šis reiškinys daugiausia problemų kelia žieminių javų pasẻliuose, o viena žalingiausių jų piktžolių yra dirvinè smilguole (Apera spica-venti (L.) P. Beauv.). Dirvinių smilguolių sẻklos buvo surinktos Lietuvos ūkininkų laukuose, kurie buvo purkšti herbicidais, bet smilguolès nebuvo sukontroliuotos. 2016$2018 \mathrm{~m}$. per vegetacinius bandymus buvo ištirti 159 sèklų mėginiai. Tyrimo metu buvo naudotos veikliosios medžiagos acetolaktato sintazès (ALS) inhibitoriai (natrio metiljodosulfuronas, sulfosulfuronas ir piroksulamas), acetilkarboksilasès (ACC) inhibitoriai (fenoksaprop-P-etilas ir pinoksadenas) ir II fotosistemos (PSII) inhibitorius (izoproturonas). Nustatyta, kad iš tirtu 159 populiacijų $43 \%$ buvo atsparios ALS inhibitoriams. Daugiausia populiacijų buvo atsparios sulfosulfuronui, mažiausiai - piroksulamui. Visos piroksulamui atsparios populiacijos buvo atsparios ir kitiems ALS inhibitoriams - natrio metiljodosulfuronui bei sulfosulfuronui.

Didejantis dirvinès smilguolès atsparumas ALS inhibitoriams labai apribos herbicidų pasirinkimą jos kontrolei pavasarị, todèl rudeninis purškimas herbicidais ateityje gali tapti labai svarbus, ypač laukuose, kuriuose ši piktžolė yra gausiai išplitusi.

Reikšminiai žodžiai: Apera spica-venti, atsparumas herbicidams, herbicidų efektyvumas, piktžolių kontrolè. 